\title{
Implications of the Events at Abu Ghraib Prison for the PfP Countries: Reflections of a Former Intelligence Officer
}

\section{G. Paul Holman *}

Iraq possesses a great and glorious civilization, dating back for several thousand years, but it abounds in contrasts and contradictions. Hammurabi's code of laws and Haroun al-Rashid's patronage of letters and the arts contrast painfully with the chaos in Baghdad today, as Iraq emerges from the wreckage of Saddam Hussein's dictatorship, endures the presence of foreign troops, and struggles toward self-rule. ${ }^{1}$ So, too, does the misbehavior of a few American soldiers in Iraq clash sharply with American ideals of human rights, respect for the Geneva Conventions, and military discipline. ${ }^{2}$ In the opinion of one Canadian journalist, "The defining image of the Iraq war will probably be Pvt. Lynndie England in a corridor in Abu Ghraib prison, holding a leash attached to a naked Iraqi man lying on the floor." ${ }^{3}$ Hundreds of other images flashed across the Internet in April and May of 2004, taking American leaders by surprise and shocking world opinion. President George Bush spoke strongly to Arab audiences on 5 May 2004:

First, I want to tell the people of the Middle East that the practices that took place in that prison are abhorrent and they don't represent America. They represent the actions of a few people. Second, it's important for people to understand that in a democracy that there will be a full investigation. ... I want to know the full extent of the

G. Paul Holman is a Distinguished Professor at the University of Maine, Orono.

1 Hammurabi, the greatest figure in the first Babylonian dynasty, was an astute diplomat and military leader, as well as a lawgiver. His reign extended from about 1792-1750 BCE. Available at home.echo-on.net/ smithda/hammurabi.html; accessed 31 May 2004. Haroun al-Rashid was the fifth and most famous Abbasid caliph. He was immortalized in the stories of the Thousand and One Nights; available at www.encyclopedia.com/html/H/ HarunalR1.asp; accessed 31 May 2004.

2 The most authoritative account yet available is "U.S. Army report on Iraqi prisoner abuse. Executive summary of Article 15-6 investigation of the $800^{\text {th }}$ Military Police Brigade by Maj. Gen. Antonio M. Taguba," NBC News; available at www.Msnbc.msn.com/id/ 4894001/5/12/2004; accessed 12 May 2004. [Cited hereafter as Taguba Report.] See also Taguba's testimony to the Senate; available at www.poe-news.com/features.php ?feat=35046; accessed 30 May 2004. [Cited hereafter as Taguba Testimony.]

3 Gwynne Dyer, "Defining Iraq war image conveys ugly symbolism," Bangor Daily News, May 2004. The extent of the resulting scandal may not be known for many months. Seven military policemen had been indicted for various crimes as of 1 June 2004, but intelligence officers and higher authorities have also been reprimanded. The U.S. Armed Forces, the Senate, and other bodies are conducting over thirty different investigations to determine what went wrong and why. 
operations in Iraq, the prison operations. We want to make sure that if there is a systemic problem ... that we stop the practices. ${ }^{4}$

Secretary of Defense Donald Rumsfeld took responsibility for the actions of those under his command, stressing that the military itself-not the media-had revealed, investigated, and announced the abuse at Abu Ghraib to the public. Rumsfeld stated:

... the United States has offered the world a seminar on what happens when things go wrong in a democracy. The world has seen those shameful pictures, but the same world has watched the United States government take responsibility and apologize to those who were wronged. It's watched senior civilian and military leadership come to Congress to testify about what was known and what has been done. It's watched a free media publish stories of all types, from the accurate, to the grossly distorted. Iraq and the watching world have seen that in our country, no one is above the law, that we are a nation governed by laws. ${ }^{5}$

Indeed, one soldier has already confessed to his crimes at Abu Ghraib and been sentenced to a year in prison. Six others were scheduled for prosecution in June 2004, and several officers up to the rank of Brigadier General were formally reprimanded, but the full extent of the scandal is still far from clear.

As a case study, Abu Ghraib raises many important questions for the PfP countries. Readers should ask how this American scandal compares with their own national experiences. How does a democratic country respond to violations of the law by its own armed forces? Who should be punished: only the low-ranking soldiers who committed the offenses, or senior officers, too, if they failed as leaders, commanders, and policymakers? What are the tools of the executive branch of government for investigating abuses? How does the parliament or congress inform the public, prevent a government cover-up of politically explosive events, and revise the country's laws to prevent future abuses? How do the information media - above all, the Internet-help the public to understand national issues? What is the role of human rights organizations (such as the Red Cross and Amnesty International) in such situations?

This article reflects upon the lessons of Abu Ghraib. Above all, it deals with issues of professional ethics and the rule of law. It first asks what went wrong at the prisonanalyzing several different aspects of the problem - and then explores the implications for national security and military strategy. The author is a former intelligence officer, who was trained in American interrogation techniques and took part in NATO exercises that simulated the harsh and realistic but legal treatment of prisoners of war. $\mathrm{He}$ examines the events at Abu Ghraib not merely in the Iraqi context, but also as a part of

4 "President Bush Meets with Al Arabiya Television on Wednesday;" available at www.Whitehouse.gov/news/rekeases/2004/05/print/20040505-2.html; accessed on 26 May 2004.

5 "Remarks by Secretary of Defense Donald Rumsfeld to the Heritage Foundation," United States Department of Defense News Transcript, 17 May 2004; available at www.defenselink.mil/transcripts/2004/tr20040517-secdef0782.html; accessed 20 May 2004. 
the global war against terrorism. That war imposes many demands on the United States and on other democracies around the world.

President Bush's National Strategy for Combating Terrorism contends that the war against terrorism is "a clash between civilization and those who would destroy it." Many PfP countries are already participating in that war, and their armed forces must be prepared for a long, complex, and unique struggle. The author believes that the democratic countries face a difficult choice between two extremes. On the one hand, they cannot win the war on terrorism unless they respect such civilized values as the human rights of prisoners - even those suspected of terrorist atrocities. But, on the other hand, they will surely lose the war on terrorism if they cannot obtain the right intelligence to prevent increasingly bloody attacks on civilian targets by secretive, tough, and disciplined enemies.

\section{What Went Wrong at Abu Ghraib Prison?}

\section{Misbehavior by Military Police}

Under Saddam Hussein, the Abu Ghraib prison was infamous for its torture chambers. Uncounted thousands of prisoners died there. In the country as a whole, the executioners of Saddam's regime had killed at least 300,000 since Saddam became president in $1979 .^{7}$

Thus it is painfully ironic that the Coalition Provisional Authority (CPA) chose not to raze this edifice of inhumanity - as it destroyed the monumental statues of Saddam-but renamed it the Baghdad Correctional Facility and filled it with an entirely new set of prisoners. Most were common criminals - burglars, looters, and car thieves - but some were insurgent fighters. A few were suspected of terrorist attacks against Iraqi civilians and coalition military targets. The prison soon became overcrowded because U.S. military authorities were slow to release people who were detained by mistake, who had no intelligence value, or who posed no threat to the community. Brigadier General Janis Karpinski, whose $800^{\text {th }}$ Military Police (MP) Brigade was responsible for Abu Ghraib and several other detention facilities, has commented that at least 60 percent of the prisoners were eligible for release, but her superiors routinely denied her requests to let them go. ${ }^{8}$

Most of the mistreatment took place between October-December 2003, at the hands of the MPs who were assigned to run the prison. Several prisoners were severely

6 National Strategy for Combating Terrorism. February 2003; available at www.Whitehouse.gov/news/releases/2003/02/counter_terrorism/counter_terrorism_strategy. pdf; accessed 22 May 2004.

7 Human rights organizations have reported 270 mass graves in Iraq as a whole, and confirmed 53 by mid-January 2004. Ibrahim al-Idrissi, spokesman for the Free Prisoners Society, believes that the total number of Iraqis killed over the past twenty years is five to seven million. National Geographic Magazine 205:6 (June 2004), 26.

8 Taguba Report, 26-27. 
beaten; guard dogs - unclean animals according to Islamic tradition-were used to intimidate and sometimes to bite the prisoners; a few prisoners may have been raped; and many bizarre sexual acts were photographed. Presumably to degrade and humiliate the prisoners, an American female soldier often posed for the cameras next to naked, shackled Iraqi men. At least one prisoner was threatened with electrical shock. In the words of Major General Antonio Taguba, the Army-appointed head of an investigating commission, members of the $800^{\text {th }}$ MP Brigade committed "sadistic, blatant and wanton criminal abuses" which were substantiated by "extremely graphic photographic evidence."9

Several American military personnel refused to take part in these grossly illegal activities and reported them to the proper authorities. An investigation was begun on 14 January 2004, leading to the criminal prosecution of some soldiers and letters of reprimand for others. Secretary of Defense Rumsfeld and President Bush were informed of the probe within a few days, and a terse report was released to the press. However, the real importance of the misbehavior did not become clear until the photographs reached the American news media (presumably via an unauthorized "leak") on April 28. As Secretary of Defense Rumsfeld told members of Congress, "I failed to identify the catastrophic damage that the allegations of abuse could do to our operations in the theater, to the safety of our troops in the field, to the cause to which we are committed." 10

\section{Unethical Interrogation Techniques?}

Even before the first reports and photographs reached the public, the scandal was already widening. The accused military policemen claimed that they were only following the orders of military intelligence officers and civilian contractors. Their abuse was supposedly calculated to "give the prisoners hell" and "loosen them up" for successful interrogation. ${ }^{11}$ In his report, Major General Taguba took their claims very seriously. He recommended that another investigation should consider the guilt of military intelligence personnel. In his view, one colonel, one lieutenant colonel, and two civilians from the $205^{\text {th }}$ Military Intelligence (MI) Brigade "were either directly or indirectly responsible for the abuses at Abu Ghraib...."12

Human rights organizations asserted that the problem was not limited to only a few soldiers. According to Pierre Kraehenbuehl, Director of Operations for the International Committee of the Red Cross, "The elements we found were tantamount to torture. ... What we have described amounts to a pattern, a broad system." ${ }^{, 13}$ Indeed, at

9 Ibid., 16.

10 Cited by Johanna McGeary, “The Scandal's Growing Stain,” Time (May 17, 2004), 28.

11 Ibid., 31.

12 Taguba Report, 49. Major General George Fay undertook an investigation of allegations against Military Intelligence personnel, but it was not available when this article went to press.

13 "Red Cross describes systematic abuse in Iraq," International Herald Tribune (8 May 2004); available at www.iht.com/articles/518957.html; accessed 20 May 2004. 
least as early as July 2003 serious allegations of abuse were reaching both military and civilian authorities of the CPA in Iraq, and they involved prisons other than Abu Ghraib. $^{14}$

By May 2004, the U.S. Congress - as well as the media and the armed forces themselves - were taking a hard look at the training manuals of U.S. interrogators and debating what techniques were legal. Their inquiries spread from Abu Ghraib to other U.S. prisons in Iraq, Afghanistan, and elsewhere. Some interrogation techniques were relatively mild: depriving prisoners of sleep; hooding or blindfolding them; keeping them in solitary confinement; and annoying them with loud American music. But other techniques were more severe: "stress positions," such as chaining prisoners for hours in painful postures; beating them; stripping them naked; and exposing them to dogs or extreme heat. ${ }^{15}$

Some of these interrogations ended with the deaths of the prisoners. According to the Pentagon, at least thirty-seven people have died in U.S. custody in Afghanistan and Iraq. Several were shot while attempting to escape or died of natural causes, but there may have been twelve criminal killings by U.S. interrogators or soldiers. ${ }^{16}$ For example, Abdul Jaleel died on 11 January 2004 in Asad after he was chained to the top of a cell door and gagged. Major General Abed Hamed Mowhoush, an Iraqi air defense officer, was reportedly suffocated on 26 November 2003 by two U.S. soldiers at a detention facility in Al Qaim. ${ }^{17}$ These cases are still under investigation, but American newspapers have already drawn harsh conclusions. In the view of the editors of the Washington Post, "It is horrifying to contemplate that U.S. interrogators have tortured and killed foreign prisoners and that their superiors have ignored or covered up their crimes - and yet that is where the available facts point." 18

14 McGeary, "The Scandal's Growing Stain," 32.

15 Ibid., 33. FM 34-52, the Army's major unclassified manual for intelligence interrogations, forbids the "use of force, mental torture, threats, insults and exposure to unpleasant and inhumane treatment of any kind." Other instructions given at the Army's intelligence school at Ft. Huachuca, Arizona, cite the Geneva Conventions in opposing "any form of physical torture," including chemicals, bondage, electric shock, mock executions, or sleep deprivation. Drew Brown, "Manual prohibits inhumane interrogations. Standards were violated at Abu Ghraib," Tallahassee Democrat (6 May 2004); available at www.tallahassee.com/mld/ democrat/news/nation/8599362.htm; accessed 5 May 2004.

16 According to Steven Lee Myers, at least eight cases of homicide or unexplained death of prisoners happened in Iraq, and four in Afghanistan. "Military Completed Death Certificates for 20 Prisoners Only After Months Passed," New York Times (31 May 2004); available at http://www.globalproject.info/art-1318.html; accessed 06 June 2004.

17 "The Homicide Cases," Washington Post (28 May 2004), A22; available at www.washingtonpost.com/ac2/wp-dyn/A61941-2004May27?language=printer; accessed 28 May 2004.

18 Ibid. 


\section{Compliance or Noncompliance with the Geneva Conventions?}

There can be no doubt that some U.S. personnel at Abu Ghraib and elsewhere violated both American laws and the Geneva Convention on Prisoners of War (GPW), which stipulates that prisoners must be "humanely treated" and "protected, particularly against acts of violence or intimidation and against insults and public curiosity." $" 19$ But were only a few MPs and intelligence officers to blame, or should senior generals and even civilian officials also be held accountable? These are complex questions, which were hotly debated as U.S. defense officials testified before the Senate in May 2004.

The Undersecretary of Defense for Intelligence, Steven A. Cambone, summarized the history of Bush Administration policy regarding the GPW for the Senate:

Early in the war on terrorism, long before the war in Iraq, the president made a determination that the Geneva Convention did not apply to Al-Qaeda detainees. That decision was made because the Geneva Conventions govern conflicts between states, and the Al-Qaeda is not a state, much less a signatory of the convention. Moreover, the conventions forbid the targeting of civilians and require that military forces wear designated uniforms to distinguish them from noncombatants. Terrorists don't care about the Geneva Convention, nor do they abide by its guidelines. ...

Nevertheless, President Bush did order-did order - that detainees held at Guantanamo be treated humanely and consistent with the convention's principles. ${ }^{20}$

Some senators and journalists suspected the government of using the harsh interrogations at Guantanamo as the model for how to treat Iraqis. They cited a memorandum to President Bush from his counsel, Judge Alberto R. Gonzales. Written on 25 January 2002, it made the following assertions:

I understand that you [President Bush] decided that GPW does not apply [to the conflict with Al-Qaeda and the Taliban] and, accordingly, that Al-Qaeda and Taliban detainees are not prisoners of war under the GPW. ... the war on terrorism is a new kind of war. It is not the traditional clash between nations adhering to the laws of war that formed the backdrop for GPW. The nature of the new war places a high premium on other factors, such as the ability to quickly obtain information from captured terrorists and their sponsors in order to avoid further atrocities against American civilians, and the need to try terrorists for war crimes such as wantonly killing civilians.

19 The full text of the 1949 document is available at www.unhchr.ch/html/menu3/b/91.htm; accessed 22 May 004.

20 Testimony of Steven A. Cambone in Taguba Testimony, 5. 
In my judgment, this new paradigm renders obsolete Geneva's strict limitations on questioning of enemy prisoners and renders quaint some of its provisions.... ${ }^{21}$

Senator Patrick Leahy of Vermont asked whether the Gonzales memorandum gave "a green light for American operators to go outside the law. ... There's a very strong suspicion that a signal was given (to troops): You go ahead and operate the way you want; we're giving you deniability." Senator Chris Dodd of Connecticut said that the memorandum "raises concerns ... that we were going to sort of walk away from the rule of law." 22

Some senators suggested that high-level officials had made the decision to suspend GPW protections for Iraqi prisoners as they had already done for Al-Qaeda and the Taliban. As evidence, they cited the visit to Abu Ghraib in August-September 2003 by Major General Geoffrey D. Miller, commander of the Joint Task Force at Guantanamo (JTF-GTMO), and particularly his recommendations on how to improve the production of intelligence information at Abu Ghraib. He advocated making the prison an "enabler for interrogation," and expected the MPs to train a guard force that would create conditions that would allow the successful exploitation of the prisoners. ${ }^{23}$ His team "observed that the application of emerging strategic interrogation strategies and techniques contain new approaches and operational art. ... [Major General] Miller's team recognized that they were using JTF-GTMO operational procedures and interrogation authorities as baselines for its observations and recommendations. ${ }^{24}$

A case in point is the use of dogs to intimidate (and in at least one case to attack) Iraqi prisoners. Some of the most outrageous photographs of abuse at Abu Ghraib show unmuzzled dogs snarling at an Iraqi man, who cowers naked against the bars of his cell. Colonel Thomas Pappas, former commander of the $205^{\text {th }}$ MI Brigade, claimed that he discussed this interrogation technique with Major General Miller during his visit to Abu Ghraib. "He said that they used military working dogs at Gitmo [Guan-

21 "Memorandum for the President. From: Alberto R. Gonzales. Subject: Decision re: application of the Geneva Convention on Prisoners of War to the conflict with Al Qaeda and the Taliban. Draft. 1/25/2002 - 3:30 pm"; available at www.Msnbc.msn.com/id/4999363/ site/newsweek; accessed 23 May 2004. The Department of State disagreed with Gonzales and argued that the GPW should apply to detainees in the conflict, although "members of Al Qaeda as a group and the Taliban individually or as a group" should not be entitled to prisoner-of-war status under the Convention. "Memorandum to Counsel for the President and Assistant to the President for National Security Affairs. From Colin L. Powell. Subject: Draft Decision Memorandum for the President on the Applicability of the Geneva Convention to the Conflict in Afghanistan;" available at www.Msnbc.msn.com/id/4999363/site/newsweek; accessed 23 May 2004.

22 Joan Biskupic, "White House memo criticized," USA Today (26 May 2004); available at www.Usatoday.com/news/Washington/2004-05-25-memo_x.htm; accessed 25 May 2004.

23 Taguba Report, 8, citing Annex 20, "Assessment of DOD Counter-Terrorism Interrogation and Detention Operations in Iraq (MG Geoffrey D. Miller, Commander JTF-GTMO, Guantanamo Bay, Cuba), 9 September 2003." Ibid. 
tanamo] ... and that they were effective in setting the atmosphere" to get information from the detainees. ${ }^{25}$ However, Brigadier General Mark Kimmitt, the spokesman for American forces in Iraq, replied that "Miller never had a conversation with Colonel Pappas regarding the use of military dogs for interrogation purposes in Iraq. Further, military dogs were never used in interrogations at Guantanamo. ${ }^{26}$

Secretary of Defense Rumsfeld claimed that the Bush Administration had never intended to deprive Iraqi prisoners of their GPW protections. On the contrary, he told the Senate that Pentagon lawyers had reviewed the interrogation techniques for Iraq and determined that they were "consistent" with the GPW. ${ }^{27}$ Judge Gonzales asserted that the abuse of Iraqi prisoners could not have stemmed from his memorandum. "If you were to ask soldiers in the field if they ever heard of my draft memo ... they would have said, 'What?'” Indeed, his memorandum had simply presented the president with various options and the arguments for and against them. "I do regret the impression that the administration is not supportive of [the Geneva Conventions], because we are." 28

Major General Miller agreed. He departed the detention center at Guantanamo Bay and was put in command of detention operations in Iraq in April of 2004. He contended that only "authorized interrogation practices" were in use. Threats, hoods, and physical contact with the prisoners were forbidden. Stress positions and deprivation of sleep were permitted, but only with approval from higher authorities. Nudity was "not one of the authorized techniques," and Major General Miller declared his own opinion that harsh methods, in general, were counter-productive. ${ }^{29}$

\section{Disorganization}

To some extent, the problems at Abu Ghraib were caused by uncertainty over who was actually in charge of the prison-the MPs or the intelligence officers. Major General Tabuga's report declared that, "There was no clear delineation of responsibility between commands, little coordination at the command level, and no integration of the two functions." 30 He found that this "ambiguous command relationship" was worsened by an order of 19 November 2003, which "effectively made an MI Officer, rather than an MP Officer, responsible for the MP units conducting detainee operations at that

25 R. Jeffrey Smith, "General Is Said to Have Urged Use of Dogs," Washington Post (26 May 2004), A01; available at www.washingtonpost.com/ac2/wp-dyn/A55703-2004May25?lan guage=printer; accessed 26 May 2004.

Ibid.

27 Time (24 May 2004), 49-50.

28 Joan Biskupic, "White House memo criticized."

29 "War and the law in Iraq: Crime and Punishment," The Economist (8 May 2004), 44.

30 Taguba Report, 37. 
facility. This is not doctrinally sound due to the different missions and agendas assigned to each of these respective specialties." 31

Amnesty International U.S.A. agreed with Taguba's assessment and faulted military leaders for removing "a major safeguard against torture." In the opinion of an Amnesty official, Curt Goering, U.S. authorities "recklessly took bad practices from Guantanamo and then applied them to Abu Ghraib. If they are serious about ending torture in Iraq, they must immediately ensure that officers in charge of interrogation are distinct from those in charge of detention., 32

\section{Bad Leadership, Poor Discipline, and Lack of Training}

Major General Taguba reported that the MPs at Abu Ghraib suffered from many problems. They were understaffed and underequipped, yet they were assigned to manage an overcrowded prison holding 6,000 people. They were constantly attacked with mortars and automatic weapons by Iraqi insurgents. Their normal mission was traffic control, and they were not trained for the much more demanding mission of handling prisoners of war and supervising their interrogation. They were reservists who had expected to go back to the United States until they received the unwelcome news that they were to assume responsibility for Abu Ghraib. Their morale was low when Brigadier General Karpinski took command of them, and she did not manage to improve it. The weather was hot, and the troops suffered from a very low quality of life. ${ }^{33}$

In spite of such extenuating circumstances, Taguba concluded that the root of the problem at Abu Ghraib was a "failure in leadership ... from the brigade commander on down." In his view, the $800^{\text {th }}$ MP Brigade suffered from "lack of discipline, no training whatsoever and no supervision. Supervisory omission was rampant." 34 Although the commander was well aware that abuses were taking place, she had made no effort to train her MPs in the requirements of the Geneva Conventions, nor to prevent future abuses.

After Taguba's findings, Brigadier General Janis Karpinski was suspended from command and given a "memorandum of admonishment." She asserted that she had been wrongly punished for the acts of others - namely, the intelligence officers and

31 Ibid., 37-38. Major General Miller strongly advocated the changes that Major General Taguba faulted. Ibid., 7-9, citing Annex 20. It is intriguing that Under-Secretary of Defense for Intelligence Steven Cambone directly contradicted Major General Taguba's testimony to the Senate. He declared that he did not believe that the order placing an intelligence officer "in charge gave him the authority to address the MPs' activities in direct op-con conditions." Taguba Testimony, 17.

32 "Iraq: Merging Responsibilities for Interrogation and Detention Stripped Protection Against Torture, Amnesty International Says;" available at http:/www.amnestyusa.org/countries/iraq/ document.do?id=E45DF2F86832D2F085256E9000741716; accessed 26 May 2004.

33 For a very explicit summary of the situation in the prison and the actions of its abusive guards, see Johanna McGeary, "The Scandal's Growing Stain,” 26-34.

34 "Taguba: No direct order given for abuse;" available at www.cnn.com/2004/ALLPOLITICS/ 05/11/politics.abuse.main//; accessed 11 May 2004. 
civilian interrogators - over whom she had no control. In her view, she was being made a "scapegoat." 35 It remains to be seen whether Congress and public opinion will remember her as a major cause of the Abu Ghraib abuses, or as the victim of a systemic failure.

\section{What Are the Implications of Abu Ghraib for the PfP Countries?}

\section{Revise the National Security Strategy and Structure}

Citizens of the PfP countries would do well to reflect on the Abu Ghraib scandal—not only its ugly photographs of gross misbehavior but also the roles of American military investigators, senators, and judges in resolving it. Above all, they should analyze it in the context of the war on terrorism - a conflict that affects all of us.

The United States, for its part, has completely redesigned many aspects of its national security structure because Al-Qaeda's September 11 attacks were so unexpected and so destructive. A major realignment of the executive branch took place, combining many different agencies and services (such as the Coast Guard, Customs Service, Immigration and Naturalization Service, Animal and Plant Health Inspection Service, and Transportation Security Agency) into the new Department of Homeland Security. ${ }^{36}$ It marked a major shift toward what might be called a "European" model of national security organization. (However, America still has no national identity card, and its major domestic counterintelligence organization - the Federal Bureau of Investigationstill answers to the Department of Justice, not the Department of Homeland Security.)

The Bush Administration has also rewritten America's key strategic documents in light of the war on terrorism. They make powerful reading for any intelligent citizen (especially teachers, students, and journalists), and they play an important role in public diplomacy, as well as in providing guidance for military decision makers. President George W. Bush declared in his 2002 National Security Strategy that international terrorists pose new and serious threats, but the spread of democracy provides an opportunity to defeat them:

Enemies in the past needed great armies and great industrial capabilities to endanger America. Now, shadowy networks of individuals can bring great chaos and suffering to our shores for less than it costs to purchase a single tank. ... To defeat this threat, we must make use of every tool in our arsenal - military power, better homeland de-

35 "General suspended over Abu Ghraib mistreatment," Taipei Times, citing Associated Press, Washington, 26 May 2004; available at www.taipeitimes.com/News/world/archives/ 2004/05/26/2003157018; accessed 27 May 2004.

36 For a full description and analysis, see National Strategy for Homeland Security. July 2002; available at www.whitehouse.gov/homeland/book/nat_strat_hls.pdf; accessed 31 May 2004. 
fenses, law enforcement, intelligence and vigorous efforts to cut off terrorist financing. ${ }^{37}$

In light of the abuses at Abu Ghraib and elsewhere, one must ask whether two of Bush's strategic tools-law enforcement and intelligence-have equal importance? Or, because of the unprecedented terrorist threats, has the collection of intelligence (as in the interrogation of enemy prisoners) taken precedence over the Geneva Conventions and America's own laws? ${ }^{38}$ The answer, at least in this author's opinion, is a resounding No. Such a view would seriously misread American intentions.

President Bush, Secretary of Defense Rumsfeld, and other American officials have asserted that America can protect human rights and respect international law at the same time as they wage an extremely brutal war. The 2002 National Security Strategy provides a global vision of these goals:

Today, the world's great powers find ourselves on the same side - united by common dangers of terrorist violence and chaos. The United States will build on these common interests to promote global security. We are also increasingly united by common values. Russia is in the midst of a hopeful transition, reaching for its democratic future and a partner in the war on terror. Chinese leaders are discovering that economic freedom is the only source of national wealth. In time, they will find that social and political freedom is the only source of national greatness. ${ }^{39}$

Elsewhere, this document asserts that, "America must stand firmly for the nonnegotiable demands of human dignity: the rule of law; [and] limits on the power of the state...." It urges Palestinians to "embrace democracy and the rule of law" while condemning "a small number of rogue states that ... display no regard for international law, threaten their neighbors, and callously violate international treaties to which they are party....",41

Yet this stress on the rule of law is somewhat inconsistent. At one point, Bush's national security strategy rejects an international legal institution that is very important to certain countries:

We will take the actions necessary to ensure that our efforts to meet our global security commitments and protect Americans are not impaired by the potential for investigations, inquiry, or prosecution by the International Criminal Court (ICC), whose

37 President George W. Bush. The National Security Strategy of the United States of America, The White House, 17 September 2002, 1; available at www.whitehouse.gov/nsc/nssall.html; accessed May 10, 2004; emphasis added. [Cited hereafter as NSS.]

38 For example, Amnesty International has asserted that, "The US-led war on terror against extremist groups such as Al-Qaeda has produced the most sustained attack on human rights and international law in 50 years...." See "Amnesty International slams US war on terror," Reuters and AP, London, 27 May 2004; available at www.taipeitimes.com/News/front/ archives/2004/05/27/2003157104; accessed 27 May 2004.

39 NSS, 1.

40 Ibid., 3.

${ }^{41}$ Ibid., 5 and 6. 
jurisdiction does not extend to Americans and which we do not accept. We will work with other nations to avoid complications in our military operations and [pursue] cooperation, through such mechanisms as multilateral and bilateral agreements, that will protect U.S. nationals from the ICC. ${ }^{42}$

Some of the PfP countries agree with U.S. policy toward the ICC, but other American friends and allies do not. All of their views will likely evolve over the next few years. The recent terrorist attacks in Afghanistan, Iraq, Russia, Spain, Israel, Saudi Arabia, and elsewhere will surely affect strategic thinking in most (if not all) of the democratic countries. Indeed, many PfP members have sent elements of their armed forces to Iraq and Afghanistan as part of the U.S.-led coalitions, and they are very likely to confront the same tensions between the rule of law and intelligence collection that exist in the American national security strategy.

\section{Revise the National Military Strategy}

The misbehavior of American forces at Abu Ghraib and elsewhere should also be analyzed in terms of national military strategy. Over the past decade, virtually all of the PfP countries have formulated their own military strategies and then revised them to reflect the changing security situation. This process should continue, as each government both informs its citizens about the latest developments and declares official policies for its own armed forces.

The war on terrorism has greatly affected the 2004 edition of America's National Military Strategy; specific strategies for combating terrorism and weapons of mass destruction also appeared in separate documents. ${ }^{43}$ Their highest priority is to protect the United States against attack.

Our first line of defense is abroad and includes mutually supporting activities with US allies to counter threats close to their source. ... Protecting the United States also requires integrating military capabilities with other government and law enforcement agencies to manage the consequences of an attack or natural disaster. ${ }^{44}$

There is a serious risk that transnational terrorist networks, rogue states, and aggressive countries could employ chemical, biological, radiological, nuclear, and enhanced high explosive weapons, as well as cyber attacks (collectively abbreviated

42 Ibid., 14. The Economist remarked that, because of the widening scandal, "the argument used to justify America's rejection of the new International Criminal Court-that its soldiers would be vulnerable to unreasonable prosecution, with necessary military actions defined as crimes-looked ever more hollow." Economist (8 May 2004), 11.

National Strategy for Combating Terrorism, February

2003; available at www.whitehouse.gov/news/releases/2003/02counter_terrorism/counter_terrorism_strategy.pdf; accessed 25 May 2004; National Strategy to Combat Weapons of Mass Destruction, December 2002; available at www.whitehouse.gov/news/releases/2002/12/WMDStrategy.pdf; accessed 25 May 2004.

44 Richard B. Myers, Chairman of the Joint Chiefs of Staff, National Military Strategy of the United States of America. 2004. A Strategy for Today; A Vision for Tomorrow (Washington, D.C.: The Pentagon, 2004), iii. 
"WMD/E"). Such adversaries, according to the new National Military Strategy, may be "less susceptible to traditional means of deterrence" than previous foes, and they "will target civilian populations, economic centers and symbolic locations as a way to attack U.S. political will and resolve." ${ }^{\text {In }}$ In the event that such enemies do "acquire WMD/E or dangerous asymmetric capabilities, or demonstrate the intent to mount a surprise attack, the United States must be prepared to prevent them from striking." ${ }^{46}$

In all of these strategic documents, the United States has both warned that terrorist attacks with WMD/E are very likely and declared that it will act preemptively to prevent them. If necessary, the United States would act alone, but it would greatly prefer to work more closely than ever before with all of the democratic countries to win the war on terrorism. According to General Richard B. Myers, Chairman of the Joint Chiefs of Staff,

The NMS (National Military Strategy) serves to focus the Armed Forces on maintaining US leadership in a global community that is challenged on many frontsfrom countering the threat of global terrorism to fostering emerging democracies. ... The United States must adopt an 'active defense-in-depth' that merges joint force, interagency, international non-governmental organizations, and multinational capabilities in a synergistic manner. ${ }^{47}$

The Abu Ghraib scandal has intensified anti-American sentiment in both democratic and undemocratic countries around the globe, discrediting American motives in the war on terrorism and making it harder to achieve the multinational capabilities that the NMS advocates. Yet the tensions between the rule of law and intelligence collection are likely to get worse, not better, because of the growing risk that terrorists will attack civilian targets with WMD/E. Future interrogators are almost certain to face what has been called "the ticking bomb scenario." 48 If they believe that a specific prisoner knows the time, place, or method of an attack with WMD/E, they will be sorely tempted to use brutal and inhumane techniques of interrogation, even though the Geneva Convention forbids them. PfP strategists are unlikely to discuss such facts in unclassified documents, but they should still reflect upon them. Their own national military strategies will be deficient if they do not examine this depressing but imminent reality.

\section{Conclusions}

It remains to be seen how the PfP countries and other democracies will deal with the threat of WMD/E attacks upon their deployed forces, if not their own national territories. Sooner or later, many of them will face the same dilemmas as the United States

45 Ibid., 1.

46 Ibid., 4.

47 Ibid., iii and 5; emphasis added.

${ }^{48}$ Chanterelle Sung, "Torturing the Ticking Bomb Terrorist: An Analysis of Judicially Sanctioned Torture in the Context of Terrorism"; available at www.bc.edu/schools/law/ lawreviews/meta-elements/journals/bctwj23_1/05_TXT.htm; accessed 1 June 2004. 
currently faces in the war on terrorism. More scandals will probably occur. Indeed, troops from Poland and other coalition countries have already been accused of abusing prisoners in Iraq. ${ }^{49}$ It will be a major challenge for all of the PfP countries first to analyze the war on terrorism, then to debate the ethics of their own treatment of prisoners, and finally to coordinate their strategies with other friendly countries.

The case of Abu Ghraib emphatically shows the power of the Internet and other electronic media. More than ever before, it is difficult for democratic governments to conduct orderly investigations of alleged abuses and to conceal embarrassing information.

The long term effects of the Abu Ghraib scandal depend, at least in part, on how fairly and openly the U.S. government deals with the abusers. Suspicions of a "coverup" will discredit the American system of justice and may reduce global support for the war on terrorism. Conversely, an impartial investigation and appropriate punishment of the guilty parties will demonstrate that the United States rejects a "double standard" and treats Iraqi prisoners just as humanely as it expects other countries to treat American prisoners - so long as they fight according to the principles of the Geneva Conventions.

Many readers of this article are probably graduates of the Marshall Center's courses in Garmisch-Partenkirchen, Germany. They may remember Colonel Nick Pratt's famous proverb: it is wrong to say that one country's terrorist is another country's freedom fighter; rather, "One democracy's terrorist is another democracy's terrorist. ${ }^{, 50}$ By the same logic, America's response to Abu Ghraib must show the world that one democracy's ethical interrogation is another democracy's ethical interrogation.

49 Polish officials contended that their troops had not mistreated Iraqi prisoners, and that the allegations were not serious. "Coalition partners accused of abuse; Prisoners alleged Poles mistreated them; Calif. Guard unit accused;" available at http://msnbc.msn.com/id/5032107/; accessed 1 June 2004.

50 Colonel Nick Pratt, USMC (Ret.), is the Director of the Program on Terrorism and Security Studies at the George C. Marshall European Center for Security Studies. 


\section{Bibliography}

Biskupic, Joan. "White House memo criticized." USA Today (2004).

Dyer, Gwynne. "Defining Iraq war image conveys ugly symbolism." Bangor Daily News (2004).

McGeary, Johanna. "The Scandal's Growing Stain." Time (2004).

R. Smith, Jeffrey. "General Is Said to Have Urged Use of Dogs." Washington Post (2004). 